\title{
Comments
}

\section{NEIGHBORHOOD POLICE DISTRICTS: A CONSTITUTIONAL ANALYSIS}

Community control of major institutional bureaucracies has been described as everything from segregation to participatory democracy. Radicals and racists support it, liberals and conservatives condemn it, and virtually everyone discusses it. Community control over public education is currently an ongoing experiment. The Office of Economic Opportunity has established neighborhood welfare councils. But serious discussion of neighborhood control of police departments lias only recently entered the public forum.

The concept of neighborhood police districts is a response to the increasing number of confrontations between residents of black communities and urban police departments. Although such confrontations do not threaten every city, they are on the increase in industralized urban centers. This Comment, in discussing community control of the police, cannot cover the many policy questions inherent in such a plan. Problems such as financing, division of neighborhoods, economy of scale, realization of manpower needs, potential corruption and specific enforcement policies are best reserved for a separate analysis.

This Comment will focus most directly on the constitutional questions that inevitably arise when the state uses race as a criterion for legal and political distinctions. Part I will examine the traditional constitutional analysis used in Baker v. City of St. Petersburg ${ }^{1}$ to strike down racial distinctions in the St. Petersburg Police Department. Part II will examine the causes of conflict between police and urban blacks and will consider some of the tragic results of that conflict. Part III will explore some of the more popular proposed solutions to this problem. Part IV will formulate a theory consistent with past decisions which will permit, if not require, the establishment of neighborhood police districts. A brief section in Part IV will consider two philosophical objections to allowing the establishment of this plan.

This Comment suggests, without presenting empirical data, that nunierous incidents of police brutality and harassinent of blacks occur without cause. In order to successfully prosecute a claim for neighborhood police districts plaintiffs must be prepared to docunient fully such instances. A bare assertion of these facts is not likely to induce a constitutional remedy from the courts.

1. 400 F.2d 294 (5th Cir. 1968). 
I

BAKER V. CITY OF ST. PETERSBURG: THE TRADITIONAL ANALYSIS

The courts have employed the equal protection clause of the fourteenth amendment extensively to combat racial and other class barriers to societal participation. Congress formulated this amendment, along with the thirteenth and fifteenth amendments, in response to the needs of a newly freed people during and after the Civil War. The original purpose of the fourteenth amendment was to protect blacks against laws passed by state legislatures which discriminated against them on the basis of race. ${ }^{2}$ Modern fourteenth amendment doctrine subjects all state classifications based on race to the closest scrutiny and places the burden of justifying them on the state. Consequently, courts have outlawed segregation in schools, ${ }^{3}$ parks, ${ }^{4}$ courtrooms, ${ }^{5}$ and restaurants. ${ }^{0}$ Courts have also held statutes and other forms of state action, not racially discriminatory but discriminatory against some otherwise oppressed class, unconstitutional by virtue of the fourteenth amendment and thus have protected critical rights such as votimg, ${ }^{7}$ the right to transcripts on appeal, ${ }^{8}$ and the right to court appointed counsel im cases of indigency. ${ }^{9}$ This modern judicial history has demonstrated the fourteenth amendment's sensitivity to the disabilities that arise from race, poverty and foreign birth-a sensitivity to the effect of legislation, regardless of its purported abstract reasonableness.

Given this historical purpose and development of the equal protection clause, the Court of Appeals for the Fifth Circuit had hittle trouble deciding in Baker v. City of St. Petersburg ${ }^{10}$ that the exclusive assignment of Negro police officers to the Negro section of St. Petersburg, Florida, violated the fourteenth amendment. The court used a traditional equal protection analysis to decide the case, and it is this analysis and this case which will act as the focal point of the problems considered in this Comment.

Twelve Negro members of the St. Petersburg Police Department brought an action attacking practices which they alleged violated the fourteenth amendment and section 202 of: the Civil Rights Act of

2. See, e.g., Slaughterhouse Cases, 83 U.S. 36 (1873).

3. E.g., Brown v. Board of Education, 347 U.S. 483 (1954).

4. E.g., Wright v. Georgia, 373 U.S. 284 (1963).

5. E.g., Johnson v. Virginia, 373 U.S. 61 (1963).

6. E.g., Lombard v. Louisiana, 373 U.S. 267 (1963).

7. E.g., Carrington v. Rash, 380 U.S. 89 (1965).

8. E.g., Griffin v. Ilkinois, 351 U.S. 12 (1956).

9. E.g., Gideon v. Wainwright, 372 U.S. 335 (1963).

10. 400 F.2d 294 (5th Cir. 1968). 
1964. ${ }^{11}$ Their principal assertion was that in assigning all Negro officers to a particular zone, the department made a racial classification proscribed by the equal protection clause of the fourteenth amendment. $^{12}$

The court opened its opinion by quoting from cases holding that classifications based on race are constitutionally suspect, subject to the most rigid scrutiny, and, in most cases, irrelevant to any acceptable legislative purpose. ${ }^{13}$ The court implicitly qualified this by suggesting that such classifications could be made if they reasonably or necessarily related to a legitimate state purpose. ${ }^{14}$ This qualification requires the court to examine the effect, both stated and actual, of such classifications, sustaming only those which do not violate equal protection.

In Baker, the city did not offer compelling reasons to sustain a classification based on racial characteristics. Indeed, the history of the St. Petersburg Police Department demonstrated a likelihood that the departinent's policy existed precisely to further racial oppression. There were no Negroes in the department until 1950.15 At that time, the department hired four and assigned thein to patrol the Negro section of town. ${ }^{16}$ There was an unwritten policy that they could not arrest a white but should call for the assistance of a white officer to make such arrests. ${ }^{17}$ When the department instituted the "zone system" of patrol, dividing the city into smaller "beats," the Negroes on the force were not assigned to any zone but to a "colored car" which responded to calls made by Negro citizens. 18 Ultimately, the department established an additional zone to include the bulk of the Negro area of the city and assigned all the Negro officers exclusively to this zone. ${ }^{19}$

Other facts evidenced the attitude of the police department toward questions of race. The department assigned two sergeants per shift, with authority over the patrolmen on duty in that shift. The only exception to this was the one Negro sergeant who the department always placed exclusively in charge of the Negro patrolmen on duty. He was never assigned the duties of the other sergeants, even when he was the senior officer present. His major function was that of "liasion" between the Chief and the Negro community. ${ }^{20}$

11. 42 U.S.C. $\$ 2000 a-1$ (1964).

12. 400 F.2d at 297.

13. Id. at 297-98, quoting McLaughlin v. Florida, 378 U.S. 184, 191-92 (1969), which, in turn, quoted Hirabayashi v. United States, 320 U.S. 81, 100 (1942).

14. See 400 F.2d at 301 n.10.

15. Id. at 295 .

16. Id.

17. Id. at 300 .

18. Id.

19. Id. at 295-96. This zone was also unique in that it was entirely overlapped by four other zones. Id. at 296.

20. Id. at 296-97. 
These practices were explained as contributing to police efficiency and effective administration. The City contended that the court should not substitute its judgment for that of the police department unless the "actions were unreasonable, arbitrary, capricious or unlawful and discriminatory"21 which, it asserted, they were not. ${ }^{22}$ The Court of Appeals for the Fifth Circuit, reversing the decision of the trial court, held that the department had failed to show that there were compelling reasons for making these classifications beyond the "good faith" behef of the Chief of Police. ${ }^{23}$

The significance of Baker for this Comment, however, is that the court of appeals implicitly recognized that reasons could exist which would be sufficiently compelling to justify racial classifications in law enforcement agencies. The court was careful to disclaim holding "that the assignment of a Negro officer to a particular task because he is a Negro can never be justified."24 These compelling reasons, it is submitted, can never be sufficient if the classification deprives a class of citizens of the right to equal societal participation. However, if a racial classification opens previously closed paths to equality, it may not only be permissible, it may be required.

The court's recogmition of circumstances sufficiently compelling to justify racial classifications in law enforcennent as well as language in other opinions striking down racial classifications only on the facts of each case, ${ }^{25}$ when combined with the realities of current police practices in the black urban ghetto, ${ }^{28}$ and a meaningful analysis of the equal protection clause $e^{27}$ provide a sound constitutional frannework for permitting, if not requiring, the establishment of neighborhood police districts with boundaries based on race as a legitimate means of affording equal protection by urban pohice. ${ }^{28}$

II

URBAN POLICE PRACTICES

The job of the police officer in the central city has become substantially more difficult in recent years. The crime rate im the country's

21. Id. at 297, quoting Baker v. City of St. Petersburg, 252 F. Supp. 397, 399 (M.D. Fla. 1966).

22. See Brief for Appellee.

23. 400 F.2d at 301 .

24. Id. at 300-01.

25. E.g., Loving v. Virginia, 388 U.S. 1 (1967); McLaughlin v. Florida, 379 U.S. 184 (1964).

26. See Part II infra.

27. See Part IV, section C infra.

28. See Part IV, section A infra for a description of a proposed neighborhood police district plan. 
most populous cities has increased substantially, ${ }^{29}$ while police department budgets have remained relatively stable. ${ }^{30}$ Although the central cities are not growing in population as rapidly as in earlier periods, the high "turn-over rate" has changed their basic character. ${ }^{31}$ New kinds of people with new kinds of problems now inhabit major urban areas. That the resulting tensions are dangerous is ainply illustrated by the fact that all seven major riots experienced by United States cities in the summer of 1964 were touched off by confrontations between white police and black ghetto residents. ${ }^{22}$

\section{A. The Dynamics of Police-Urban Black Relationships}

The white police and the urban black distrust and fear each other to the point that they are reluctant to encounter each other and, when they do, the encounter is often unsatisfactory to both. Ironically, this relationship stems from identifying characteristics that both the police and the black ghetto residents share as a class: both are isolated from the rest of society and each fears a "symbolic assailant." Unfortunately, the police and the black are each other's "symbolic assailant."

Isolation is a plenomenon which occurs when a particular group has common goals or attitudes which, in some way, appear to be in conflict with those of the general public. ${ }^{33}$ Fear of the "symbolic assailant" is a shorthand method of expressing a generalized fear of a particular group defined by some classificatory characteristic such as its race $^{34}$ The generalized character of the fear and the inability to distinguish between members of the feared class stems from the association of the classificatory characteristic with the unsatisfactory encounters one has had with members of the defined class. In white police-black ghetto resident relationships the problem is compounded, since the defining characteristic of each group of symbohic assailants is the same characteristic which is at the root of that group's isolation. Thus, one must analyze police-black relationships in light of the social dynamics of both groups.

29. PRESIDENT's COMMISSION ON LAW ENFORCEMENT AND AdMINISTRATION OF Justice, The Challenge of Crime in a Free Society 22-29 (1967) (figs. 3-6, tables $6,8,9)$ [hereinafter cited as CRIME COMM'N].

30. PRESIDENT'S COMMISSION ON LAW ENFORCEMENT AND AdMTISTRATION OF Justice, The Challenge of Crime in a Free Society; Task Force Report: Crime AND ITS IMPACT-AN AsSESSMENT 55 (1967) (table 9).

31. Report of the National AdVisory Commission on CtVIL Disorder 236-50 (Bantam ed. 1968) [hereinafter cited as RTot COMM'N].

32. See Comment, Black Power Advocacy: Criminal Anarchy or Free Speech, 56 Calif. L. Rev. 702, 727 (1968).

33. J. Skolnick, Justice Without Trial: Law Enforcement in Democratic SocIETY 49-51 (paperback ed. 1966).

34. Id. at $45-48$. 


\section{The Police}

The police in modern American cities elicit mixed feelings from the majority of the public. A middle class urban resident generally meets the police in unpleasant circumstances: either lie has done something wrong calling for police action or lie has been injured and requires the assistance of the police. ${ }^{35}$ Unless the police satisfactorily help the person requesting assistance-which is rare ${ }^{36}$ - the public maintains a negative attitude toward the police exemplified by the response "why do the police waste their time giving me a parking ticket when crime is running rampant on the streets?"

This reaction to the police by the great majority of middle class urban residents lias lead to the isolation of the police into a separate culture. Coming largely from lower and working class backgrounds, ${ }^{37}$ policemen aspire to attam middle class affluence while at the same time maintaining working class social attitudes. ${ }^{38}$ This plenomenon theoretically could manifest itself in two ways. First, the police culture could ignore middle class demands whenever possible and establish its own group-defined standards of law enforcement. Second, it could zealously adhere to those demands in an attempt to gain middle class acceptance. It appears that the police have adopted elements of both these possibilities which, combined with fear of the "symbolic assailant," lead to unfair treatment of black ghetto residents.

Middle class standards not only define when police action is required, they define the symbolic assailants by defining the unusual. One of the reasons police find many nnore violations of substantive law and nany more symbolic assailants in black ghettoes is that these areas generally do not conform to the standards set by white middle class society. White neighborloods are generally divided into separate commercial and residential areas; black neighborhoods often maintain no sucl distimction. In white areas it is the exception to find men in the streets during the day; im black areas, because of high unemployment and "grave-yard shift" jobs, it may be the rule. In white areas, with pleasant homes, color televisions and air conditioners, it is unusual to find groups of teenagers on the streets after dark; in black areas without these advantages it is a cominon occurrence. These unusual situations provide many opportunities to find substantive violations of the law: loitering, and curfew violations-and symbolic assailants: potential muggers and street gangs-not found in white middle class neighborhoods.

35. Id. at 55-56.

36. A. Niederhoffer, Behind the Shield: The Police in Urban Society 174 (Anchor ed. 1968).

37. Id. at 39,41 .

38. Id. at $114,159-60$. 
There is little question that police as a group view blacks differently than whites. In one study, over 50 percent of the police officers assigned to black districts expressed extreme prejudicial attitudes towards blacks, one percent expressed sympathetic attitudes and 25 percent expressed mildly prejudicial attitudes. ${ }^{39}$ In Watts, prior to the riot, police referred to niglitsticks as "nigger-knockers" and displayed pictures of Eleanor Roosevelt on the precinct station walls with the caption "nigger-lover."40 Elsewliere in California, police distributed literature supporting the anti-fair lousing amendment ${ }^{41}$ and one police station became a hate-literature distribution center. ${ }^{42}$ There has been a recent increase in police membership in the John Birch Society and other right wing groups. ${ }^{43}$

These police attitudes have not left behavior unaffected: they are reflected in the way blacks are treated in confrontations with police. Police use curfew laws, seldom enforced in white communities, to disperse groups of black youths on the streets after dark. ${ }^{44}$ When such laws are enforced in white communities, the youths are generally taken home; in the black community they are most frequently "frisked" or otherwise harassed in a police car, taken to a district police station, or dropped off in a distant neighborhood-perhaps that of a rival gangand left to get home on their own. ${ }^{45}$ The impact of sucli treatment is self-evident.

In niany contacts with blacks, police refer to them in a variety of derogatory terms. ${ }^{40}$ Although these verbal assaults are not physically

39. RIot COMM'N, supra note 31, at 306.

40. R. Conot, RIvers of Blood, Years of Darkness 40, 173 (Bantam ed. 1968).

41. A Report of a Research Study Submitted to the President's Commission on Law Enforcement and the Administration of Justice, The Police and the Community, pt. IV, at 123-24 [hereinafter cited as CRIMe Comm'n, The Police AND THE COMMUNITY].

42. R. Conor, supra note 40, at 172.

43. E.g., id. at 172 (John Birch Society); id. (Fire and Police Research Association); CrIMe Comm'n, The Police AND THE COMMUNITY, supra note 41, pt. III, at 48 (Fraternal Order of Police). This tolerance for membership is not present with regard to "leftist" groups. E.g., R. Conot, supra note 40, at 173 (CORE); CRIME CoMm'N, The Police AND THE COMMUNITY, supra note 41, pt. III, at 160 (Black Muslims). See also A. NeIDERHOFfer, supra note 36, at 58.

44. CRIme Comm'n, The Police and the Community, supra note 41, pt. II, at $147-50$.

45. Id. pt. III, at 114. Cf. id. pt. II, at 82 .

46. Name calling is considered by blacks to be the most pervasive and most disliked form of police brutality. Id. pt. II, at 84. The police departments of several cities lave found it necessary to issue orders to officers not to use abusive language. E.g., Chicago Police Department General Order 66-9, April 22, 1966 (on file with the California Law Review):

II. Individual Rights

D. At all times Department personnel will:

1. never show any bias or prejudice against any race, religion, or other 
damaging, blacks resent such treatment, and it may ultimately be the most damaging form of brutality. Rather than an assault on the physical integrity of the individual, it is an assault on the ego and implication of lack of individual worth. This is an extension of the degradation imposed on blacks in slavery and during the period immediately following Reconstruction. It is part of a pattern of conduct which has not only made the white stereotype of blacks a self-fulfilling prophecy but has led to the downgrading of the black's self-esteem. ${ }^{47}$ This psyclrological wound is mucls more damaging and mucls harder to heal than physical wounds.

That is not to say that physical wounds do not exist. When police officers leave the station liouse repeating the slogan "L.S.M.F.T.""Let's Shoot a Mother-Fucker Tonight"-the potential for violence is great. ${ }^{48}$ The prevailing attitude among police officers is that violence is a good preventative measure and a means of self-protection. ${ }^{40}$ This violence can be manifested in nany ways. Arrests for minor offenses and field interrogations give police an opportunity to perpetrate violence and to liumiliate suspects through "spread-eagle frisks." "Ao "Alley justice" in the form of systematic police beatings of local "troublemakers," while not common, still exists in the urban ghetto. ${ }^{51}$ Finally, when

group or individual.

2. act, speak and conduct themselves in such a inanner as to treat all persons with complete courtesy and with that respect due to every person as a human being.

3. never "talk down" to any group or individual or engage in the use of derogatory terms such as: "nigger," "boy," "spic," "wop," "kike," "chink," "shine," "burrhead," "dago," "polack," "bohunk," and the like.

4. Ineet all persons half way and not insolently require citizens to come to them in traffic and other stops.

47. See generally W. GRIER \& P. COBBS, BLACK RAGe (Bantam ed. 1968). The thesis of this study by two black psychiatrists is that the history of slavery and the establishment of white standards which blacks, by definition, cannot achieve has caused the black to enter a love/hate relationship with white society. By establishing a white standard of beauty, for example, white society has forced black women to consider themselves ugly while, at the same time, they try to achieve the unachievable, e.g. by having their hair straightened and using bleaching creans. This anomoly, the authors feel, permeates all facets of life in the black cominumity and thus makcs 300 years of history a reality today. It effects interpersonal relationships between blacks and whites and among blacks. The solution offered by Grier and Cobbs is simple: "Get off our backs now!" This Comment suggests that the most satisfactory place to start getting off the black's back is in his own coinmunity and the inost substantial force that white society ean take off his back is the one force that always reminds him of white superiority-the police.

48. R. Conot, supra note 40 , at 40.

49. J. SzolNICK, supra note 33 , at $45-48$.

50. Riot Comm'n, supra note 31, at 304; CrIme Comm'n, The Police and the CommunTTY, supra note 41 , pt. II, at 88.

51. Police attitudes toward what they consider things within their discretion is perhaps best illustrated by a recent event in San Francisco. Three black women were 
a riot breaks out in a black community, the general police inclination is to suppress it with uncontrolled violence. ${ }^{52}$

Not only does brutality result froin contact with the police, it also emanates from and is inanifested by lack of contact. Instead of walking a beat and getting to know the people in the neighborhood-both the troublemakers and the "solid citizens"-the policeman cruises around in his car aloof from the everyday hes of those he patrols. ${ }^{53}$ In fairness to the police, this is often needed for both efficiency and self-protection, but the result is nonetheless unsatisfactory. The police officer finds himself imputing the acts of some to the lives of all and acting in response to this, as he has no other relevant method of making distinctions. Black faces mean trouble for him regardless of the actual circumstances and lie acts accordingly.

Finally, brutality exists in the lack of enforcement of certain laws in ghetto areas. A common complaint of ghetto residents is that unless the officer wants to harass or intimidate an offender or the community at large, he allows vice in the form of prostitution and narcotics sales to go on in his presence. ${ }^{54}$ Residents also regularly complain that policemen are slow in responding to requests for help and often never come at all. ${ }^{65}$ This is the essence of psychological degradation. In effect, the police are telling the black community that it is not a part of the white society and that it slould solve its own problems, but if it ever interferes with white society there will be serious repercnssions.

\section{The Urban Black}

In a different way, the urban black is also isolated from the general public. The history of black America, both culturally and politically, ${ }^{66}$

hit by another driver. The police forcibly stopped them from plotographing the other driver, beat them, threw them violently into a "paddy wagon" and "subdued" them with a strong chemical irritant used normally by police in riot situations. San Francisco Chronicle, Feb. 11, 1969, at 1, col. 1. The police response to a proposed investigation of the incident was not protestations of innocence, but a categorical assertion that there should be no investigation and that police conduct slould, in general, be free from scrutiny by any official body. San Francisco Chronicle, Feb. 12, 1969, at 1, col. 1. The thrust of this position does not relate to police review but to police practices. Implicit in their argument is the belief by police that such methods are effective aud necessary means of establislimg respect for the police and keeping "troublemakers" in their place. By taking this position in what, to the general public, unust seem an atrocity, the police adequately demonstrate their unique attitudes about the nature of law enforcemeut as applied to blacks.

52. See RIOT CoMM'N, supra note 31, at 334-35.

53. Id. at 304-05.

54. Id. at 307-09.

55. Id. See also J. Hersey, The Algiers Motel InCident 88-89 (Bantam ed. 1968).

56. For a good presentation of black history, see E.F. FrazIER, THE NEGRO IN THE UNITED States (2d ed. 1957). 
has put the modern black in a socially distinct group. As a slave, the black man was torn from his wife and children or forced to witness their abuse; as a "free" man, the black is again torn from his family by the combination of job and educational discrimination and such institutions as the Aid to Families with Dependent Children's penalty for family cohesiveness. ${ }^{57}$ Thus the black man, treated differently than the white, is as isolated from the general public today as he was 300 years ago, for the same forces which operated on his life then continue to operate on it today.

These isolating forces contribute to the claracterization of the pohice as symbolic assailants. In fact, the entire white world is a black's symbolic assailant, but the policeman is often the most frequently encountered white, and the encounter is often hostile. Althougl the white law enforcement officer may feel justified in participating im evictions, to the black who had to pay twice the value of his run-down apartment he is the oppressor. To the black who, because of madequate education, inability to travel to other sections of town, and inability to get adequate financing, is forced to sign an installment contract for two or three times the value of the goods, ${ }^{58}$ the sheriff involved in repossession is the oppressor. A policeinan may be justified in dispersing a group of black youtlis standing on a street corner at night; but to the youth who lias nowhere else to go and nothing else to do, the policeman is the oppressor. The policeman who arrests a black for selling drugs, running numbers, or being drunk is merely enforcing the law as he is told to; but to the black he is an instrument of the system which forces him to illicit occupation to survive and to the escape of drugs and drink when he can survive no longer. ${ }^{50}$ Thus, the urban black has as persuasive reasons to be isolated from white society and to fear the white policennan as the white policeinan has to fear the black.

57. Under the Social Security System, families that have needy children due to the absence of a parent from the home are entitled to welfare grants, while families with neither parent absent, but in similar economic circumstances, receive no such grants. 49 Stat. 627 (1935), 42 U.S.C. $\$ \$ 601-09$ (1964). It has been suggested that this encourages fathers to leave their families in order to provide them with additional income.

58. Riot Comm'N, supra note 31, at 274-77.

59. See generally Autobiography of Malcolm X (paperback ed. 1966). The fact that the urban black really does see the white world as an entire system which acts to oppress him in a unified way is evidenced by the success of the Los Angeles Herald Dispatch, a black newspaper which condemns virtually all white factions. The paper expounds the editor, Mrs. Pat Alexander's, "political philosophy:" Anti-Semitism, opposition to the Vietnam war, anti-Communism, pro-Castro and Chinese Communism, and distrust of the KKK, American Nazis, civil rights movement, NAACP, CORE, trade unions, and certain elements in the John Birch Society and the Republican Party, all of which are financed by a combination of Jews and liberals in "The Antichristian Communist Conspiracy." R. CONOT, supra note 40, at 298-301. 
It is not unlikely to expect increased violence directed toward the police in response to the abuses which define the police as symbolic assailants to the black ghetto resident. Unfortunately, this violence can do hittle more than reinforce the policeman's view of the black as a symbolic assailant. This, in turn, will lead to greater police abuses which will continue to isolate them from the general public, and to greater black distrust of white society which will continue to isolate them from the decisionmaking process. Current institutions cannot adequately cope with this problem, as it is the institutions themselves which are creating it.

\section{Summary}

The mutual isolation and fear of the symbolic assailant by both blacks and the police can hardly help but lead to conflict between the two groups. Police in many black neighborhoods, in an effort to maintain "law and order" while at the same time protect themselves from danger, often abuse their discretion when dealing with blacks. In return for this abuse, the urban black often manifests his hate and fear of the police, reinforcing the police belief that their actions are justifiable. This circular evolution is present to some degree in most major urban centers and shows no signs of diminishing in the future.

\section{B. The Fourteenth Amendment and Police Practices}

Although the fourteenth amendment's equal protection clause has had a controversial and complex development, ${ }^{60}$ it is now settled that the equal protection clause prohibits racial discrimination adversely affecting rights to education and sufferage. ${ }^{61}$ Logic demands that racial discrimination which takes the form of mental and physical assaults cannot coexist with proscriptions against educational discrimination. ${ }^{62}$ Burdens on communications with the institution that enforces lawsthe police-cannot coexist with proscriptions against burdens on communications with the less visible legislatures through voting. ${ }^{63}$ The courts cannot fail to take cognizance of these inconsistencies.

\section{Classifications Based on Race}

There is no doubt that police must be allowed to make certain

60. See Avins, Equal "Protection" of the Laws: The Original Understanding, 12 N.Y.L.F. 385 (1966).

61. This Comment does not completely disregard controversial areas of development of the fourteenth amendment. Indeed, application of a seemingly different standard for beneficial racial classifications is perliaps the most controversial interpretation of the fourteenth amendment to date.

62. E.g. Hobson v. Hansen, 269 F. Supp. 401 (D.D.C. 1967).

63. Yick Wo v. Hopkins, 118 U.S. 356, 370 (1886). 
classifications in order to enforce laws adequately and efficiently. If all discrimination were proscribed, the police would be completely bogged down with the enforcement of "unimportant" laws while major crime ran rampant. ${ }^{64}$ However, police cannot make unreasonable classifications. In Yick Wo v. Hopkins ${ }^{65}$ all Chinese owners of cleaning establishments were denied statutorily required permits to operate their busmesses. Although there were 80 similarly situated establishments run by whites, only the Chimese were denied permits. The United States Supreme Court, in overturning the convictions for violation of the ordinance, was forced to the conclusion that the discriminatory enforcenient of the permil ordinance constituted a violation of the equal protection clause-regardless of the original intent of the ordinance itself-as only racial hostility could explaim that enforcement. ${ }^{60}$

Racial classifications will be considered at length below, ${ }^{67}$ but for now it is sufficient to say that in the enforcement of the law, the fourteenth amendment prohibits any such classifications. It is clear, however, that they are being made. Just as in Yick Wo, equal laws are being administered with "an evil eye and an unequal hand, so as practically to nrake unjust and illegal discriminations between persons in similar circumstances . . .." Although a high crime rate may justify certain discretionary acts by police within legal guidelines, it does not justify brutal treatment as a means of control. It does not justify slow responses to calls for assistance by residents or lawful but unnecessary arrests when none would be made under the same conditions in other areas. Finally, it does not justify police use of derogatory remarks and treatment of blacks as second class citizens. Although each incident of discriminatory police abuse may not individually constitute a denial of equal protection, the cumulative effect of such incidents, considered under the heading of "police practices," clearly constitute such a denial ${ }^{69}$ as they subject blacks to the very abuses feared by the framers of the fourteenth amendment.

\section{State Action}

Under the rule first promulgated in the Civil Rights Cases, ${ }^{70}$ discriminatory treatment is a violation of the fourteenth amendment only

64. Note, Equal Protection as a Defense to Selective Law Enforcement by Police Officials, 14 J. PUB. L. 223 (1965).

65. 118 U.S. 356 (1886).

66. Id. at 373-74. Although the classification in Yick Wo was based on race, the case turns on the reasonableness of the classification generally.

67. See Part IV, section B infra.

68. Yick Wo v. Hopkins, 118 U.S. 356, 373-74 (1886).

69. Cf. Edgar Cahn, Introductory Address to Colloquium on Legal Education, Boalt Hall, University of California, April 18, 1969.

70. 109 U.S. 3 (1883). 
if the treatment resulted from state action. As originally construed, state action was thought of most clearly as acts of the state legislatures. This has been extended, however, to a point probably not contemplated by the justices who originally formulated the concept. Shelley $v$. Kraemer ${ }^{71}$ held judicial enforcement of private restrictions to be sufficient state action to invoke the fourteenth amendment. Although Shelley has never been relied on, recent decisions have broadened the definition of state action, and, perhaps, may have abrogated the need for its presence. ${ }^{72}$

It is clear that conduct of police officers while on duty and in uniform falls within any definition of state action. In Ex parte Virginia ${ }^{73}$ the Supreme Court spoke to this question and said that a person acting in the name of the state and by virtue of his position with the state is clothed in the power of the state, and the act of one is the act of both. ${ }^{74}$ Were this not the case, the Court reasoned, the state would be immune from the obligation of insuring equal protection of the laws, for a state cannot act other than through its agents. ${ }^{75}$

The application of this doctrine to police officers was a logical extension of the philosophy it expressed. In two cases decided by the Supreme Court presenting this very question, the Court not only included police officers within the ambit of those constrained by the requirements of the fourteenth amendment, it expressly stated that the state was not relieved of responsibility merely because the officer in question exceeded the authority granted him. ${ }^{76}$ In Baldwin v. Morgan, ${ }^{77}$ the United States Court of Appeals for the Fifth Circuit reversed a lower court decision denying relief to plaintiffs who were forcibly reinoved from a railroad station by police officers because they were black. The court rejected the proposition that the actions were not "under color of law" because there was no specific statute authorizing segregation by race, but were, im fact, an abuse of authority by pohice

71. 334 U.S. 1 (1948).

72. See Katzenbach v. Morgan, 384 U.S. 641 (1966); United States v. Guest, 383 U.S. 745 (1966). Morgan intimated that Congress can make an independent determination that a practice contains the requisite state action and that determination is not subject to review. In Guest, although the Court's opinion contained the requirement of state action for Congressional enforcement of the fourteenth amendment, six Justices in two separate opinions said that state action was not a prerequisite to such enforcement. 383 U.S. at 761 (Clark, J., joined by Black, J. and Fortas, J., concurring); id. at 774 (Brennan, J., joined by Warren, C.J., and Douglas, J., concurring).

73. 100 U.S. 339 (1897).

74. Id. at 347 .

75. Id.

76. United States v. Price, 383 U.S. 787 (1966); United States v. Screws, 325 U.S. 91 (1945).

77. 287 F.2d 750 (5th Cir. 1961). 
officers. The court classified this as prohibited state action, saying:

If city policemen, with the color of office which their uniform, badge, display of authority and available arms reflects, undertake as policemen to subject persons to treatment which denied them a constitutionally protected right, it is state action. It is state action though in excess of actual legal authority or even if done without formal authorization. ${ }^{78}$

It is clear that laws authorizing discriminatory treatment of citizens on the basis of their race by police are unconstitutional. It is also clear that these same acts are not cured of their constitutional infirmity by the assertion that the police are taking such actions on their own initiative. By participating in such behavior while on duty, giving the appearance of acting officially and with the support of the discretion vested in them by the very nature of their work, ${ }^{70}$ policemen are using the authority of their office to perpetrate acts of discrimination against blacks. This is most certainly state action prohibited by the fourteenth amendment.

\section{III \\ PROPOSED ALTERNATIVES}

It is apparent from the previous discussion that something is critically wrong with wany contemporary urban police departments and practices. The incidents of racial brutality by police have gone beyond the point where they can be explained away as unusual or isolated. They are sufficiently serious to establish that an entire class of people las been deprived of constitutional rights. Bodies from Presidential Commissions $^{80}$ to local city councils ${ }^{81}$ have recognized the severity of this deprivation and have proposed various solutions. This Part criticizes a number of these currently popular solutions. Aside from criticisms which may be made of individual solutions, the major and fatal flaw from which they all suffer must be emphasized at the outset: They are all presented within the context of a police department controlled by a white administration whose personnel have risen through the ranks

78. Id. at 757.

79. See J.Q. WiLson, VARIETIES OF POLICE BeHAVIor 278 (1968).

80. See RIOT COMM'N, supra note 31, at 299-322; CRIME COMM'N, supra noto 29 , at $91-124$.

81. See Proposed Amendment to the Charter of the City of Richmond, California; Proposed Ordinance for City of Berkeley, California (on file with the California Law Review). Although there are political obstacles to the passing of such legislation, the various city councils are aware of current police problems. Both the Berkeley and Richmond city councils openly solicited suggestions from residents as to possible plans for improving their respective police departments. Berkeley has gone so far as to appoint a citizens committeo to study the problems and proposed solutions. 
from beat patrolman-a system which inherently perpetuates discriminatory law enforcement by racial classification. Whatever inerit the individual proposals inay have is overshadowed by this pervasive flaw. The mechanics of the flaw are more fully set out in section A below and are apphicable to all of the proposals described in this Part.

\section{A. Increasing the Number of Black Policemen}

Increasing the black representation in urban police departments has been urged as a starting point for improving police-community relations, in the hopes of reducing the friction that often leads to abusive practices. ${ }^{82}$ This suggestion presents two basic problems. First, it is unlikely that there will be a significant increase in the number of black policemen in the near future. Second, there is substantial doubt that even a significant increase would result in greater harmony than now exists.

Under a white administration, police work makes unacceptable demands upon most blacks. Many of those who now meet the age qualification grew up in the central city and their experiences with the police have convinced them that the police exist primarily to keep the black in his place and protect the white power structure. ${ }^{83}$ To become a policeman in the present police structure is to reject any remaining racial pride, to accept the white stereotype of the black, and effectively become as "white" as the purest Caucasian. ${ }^{84}$ Black youth of today are unwilling to do this. ${ }^{85}$

In addition, present standards make it difficult for any member of a culturally deprived group to becoine a policeman. Most departments require at least a high school education, ${ }^{86}$ which many blacks do not have. ${ }^{87}$ Physical qualifications, while certainly reasonable, often preclude black youths who have lived all their lives on subsistence diets. ${ }^{88}$ Many black youths have lad at least one "run-in" with the police ${ }^{89}$

82. See RIot COMm'N, supra note 31, at 315-17; CrIme Comm'n, supra note 29, at 101-02.

83. Crime Comm'n, The Police and the Community, supra note 41 , pt. II, at 98-107, pt. III, at 113-36.

84. If this rejection is not an actual one, it is at least perceived as one by ghetto residents. See notes 92-94 infra and accompanying text.

85. If ghetto youths are going to allow theinselves to be "bleached," it is more likely that they will choose a profession which will not constantly remind them of their "blackness."

86. See President's Commisston on Law Enforcement and Administration of Justice, The Challenge of Crime in a Free Society, TASK Force Report: The Police 169 (1967) [hereinafter cited as Crime Comm's, TASK Force Report: The POLICE].

87. See id.

88. See RIOT CoMM'N, supra note 31 , at 269-72.

89. See Crime Comm'n, TASK Force Report: The Police, supra note 86, at $169,171$. 
and any arrest record is often disqualifying. ${ }^{90}$ Finally, those who do meet all the requirements are highly sought after by private industry and Federal law enforcement agencies who want and need all the qualified individuals they can get, regardless of race. ${ }^{01}$

Even if a sizeable number of blacks could be recruited, the prospects for better understanding are slim. As pointed out above, a black joining white society's police department must reject his "blackness" and adopt a white moral standard. ${ }^{02}$ To prove his rejection and to advance in the department, he must constantly remind his white companions that he is not one of the "niggers" they encounter in the streets. ${ }^{93}$ The best way to do this is to adopt the practices of white officers. Consequently, in many major cities, the feeling among the black community is that black officers are more brutal, abusive and condescending than white officers, and thus pose a greater threat to police-community relations. ${ }^{04}$

A variation of the proposal to increase black representation in the police department is the exclusive assignment of black policemen to black neighborlioods. This, it is argued, would remove the need for black officers to act brutally to impress their fellow officers. It is by no neans clear that this would provide substantial improvements.

The method commonly used to determme if an officer maintams a "clean beat" is to count arrests and compare them with past performance in that beat. ${ }^{05}$ This has led to frequently heard complaints of "quota systems." Although no formal quotas are ever established, substantial pressures exist to maintain arrest levels. This system, if crude, is not a completely unrehiable index of performance. In ghetto areas, however, these "standards" have been established through years of oppressive tactics. A black officer would be hard pressed to maintain these levels without maintaining the saine techniques.

Finally, black officers will continue to be regarded by many black residents as "occupying soldiers" of the white power structure. Ghetto residents know that local beat officers are responsible to white sergeants who are nltimately responsible to white chiefs. ${ }^{98}$ This hierarchy is not lost on blacks, whose general complaints often center around the white "nıamipulation" of the black. Exclusive assignment of blacks to black

90. See id.

91. See Rrot Comm'N, supra note 31, at 316. at $93-94$.

92. CRIME COMM'N, The Police AND the COMMUNTTY, supra note 41, pt. II,

93. Id. pt. II, at $93-94$, pt. III, at 111 .

94. Id. pt. II, at $93-94,101, \mathrm{pt}$. III, at 116.

95. A. NemerrofFer, supra note 36 , at $56-58$.

96. See generally W. GRIER \& P. COBBS, supra note 47 for a discussion of the psychological implications arising from white domination of blacks. 
neighborhoods by a white administration can only reinforce the feeling that white political and economic powers are continuing to use the black community to achieve their own ends.

Integrated patrol units are a further variation of increasing the number of blacks in the department and consequently suffer from the same inadequacies. Sending black and white officers to the ghetto together affords residents a constant reminder of the black officer's abandonment of his "brothers," and pressures black officers to dernonstrate that abandonment constantly to his white partner. Furthermore, given the basic hostility of white officers toward blacks in general, ${ }^{97}$ the potential racial friction in each patrol car could easily become a serious problem. ${ }^{98}$

\section{B. Psychological Testing}

The use of psychological testing to screen out candidates for police work who may have prejudicial attitudes has been proposed and is currently being used by some departments. ${ }^{\circ 9}$ In an age of unparalleled medical and scientific advances, psychological testing has cone of age as psychologists have put in perspective both the advantages and limitations of sucli tests in making predictions about behavior. Without going into the question in great depth, it is necessary to examine some of the limitations on testing when applied to police departments.

There is no serious dispute as to the improvement in quality of police officers hired when screened by tests to determine potential racism. Such a program is certainly more satisfactory than uncontrolled hiring or superficial questioning. However, the difficulties psychologists encounter in developing such tests must not be underestimated; nor sliould the adequacy of such tests in solving the problems discussed in this Comment be overestimated. Racism, police behavior, and preappoimtment attitudes are not simiple two-dimensional variables, but operate in a complex system. Consequently, the problem of scoring and scaling test results into a useful analysis is complicated although not insoluble. The kinds of questions that will reveal racist attitudes are not yet sufficiently developed and may ultimately require a depth of inquiry into potential police officers' lives which borders on invasion of privacy and may deter qualified persormel from even applying. Finally, racism may manifest itself in ways that are currently unpredictable..$^{100}$

97. See note 31 supra and accompanying text. See Crrme COMm'n, The POLICE AND THE COMMUNITY, supra note 41, pt. III, at 192-94.

98. It does not take much imagination to recognize the potential effect on police efficiency resulting from incompatibility of patrol partners.

99. CRMMe COMM'N, TASK ForCe RePORT: THE POLICE, supra note 86, at 129-30, 164.

100. Interview with Prof. R. Jarrett, Psychology Department, University of California at Berkeley, in Berkeley, California, Dec. 12, 1968. 
These problems are coinplicated by a built-in factor which diminishes the value of all attempts at future predictions based on present data: the standard deviation. No test which attempts to predict belravior is 100 percent accurate and consequently two kinds of risks are present: The risk that a person will be selected for employment after receiving a satisfactory test score who will turn out to be unsatisfactory; and the risk that a person will receive an unsatisfactory test score and thus be rejected when, in fact, he would have been satisfactory. There is no way of saying for certain how often these risks will materialize, but even in simple two-dimensional variables they occur quite often. Given the complexity of behavior desired to be predicted, it is possible that for any one individual the results are only slightly more likely to be correct than they are to be incorrect. ${ }^{101}$ Furthermore, these two risks work in opposition to each other to make the problein even more severe. The number of unsatisfactory policemen hired can be reduced by raising the qualifying score, but this will increase the number of qualified candidates who will be rejected; the number of qualified candidates rejected can be reduced by lowering the qualifying score, but this will increase the number of unsatisfactory candidates who will be accepted. Given all this, unless the qualifying standard is extremely high, it is not reasonable to expect any drainatic improvement in the proportion

101. The following graph demonstrates the problem:

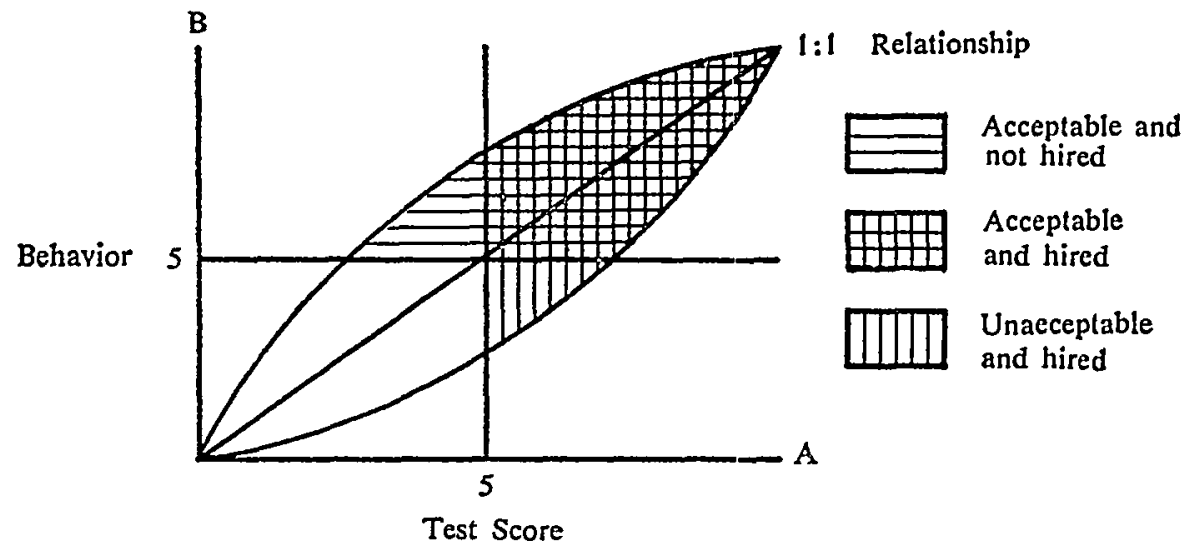

The 1:1 relationship line indicates a perfect relationship between test scores and behavior; thus, any given test score would pinpoint a certain quality of behavior. If tests were perfect measures of later behavior, it would be a simple matter to say that all candidates with a score of 5 or better would be hired by the police department. In fact, the relationship between test scores and behavior more nearly approximates the area included between the curved lines. Looking at the graph, the results of this less than perfect relationship can easily be seen. By selecting 5 as a qualifying score, a significant percent with this or higher would not prove acceptable but would be hired and a significant percent scoring below 5 would be acceptable but would not be hired. For a more complete discussion of the problem, see Taylor \& Russell, The Relationship of Validity Coefficients to the Practical Effectiveness of Tests in Selection, $23 \mathrm{~J}$. APPLIED PSYCHOLOGY 565 (1939). 
of satisfactory policemen in any moderately sized department. ${ }^{102}$ And, of course, high standards present the problem of insufficient numbers of police, particularly in a period of an initial shortage of interested applicants.

All of this is not to suggest that psychological testing should not be used. It is clear that setting even low standards of acceptable test scores will not produce a worse result than an intuitive system with no such control. ${ }^{103}$ However, the problems present in psychological testing suggest that it is not a cure-all for ending police-community relations problems.

\section{Higher Standards}

Most recommendations regarding police reform include raising the minimum level of education required for entrance into the police force and, accordingly, increasing the starting salary offered. ${ }^{104}$ This plan has two major weaknesses, beyond the general problem of the white administration. By raising education requirements, the department will necessarily reduce the nuniber of blacks otherwise qualified for membership in the departinent. ${ }^{105}$ This will reinforce the black community's preconceived ideas that the police department is racially prejudiced.

Furthermore, although there is soine correlation between levels of education and racial attitudes, the relationship is not causal. The underlying factor appears to be socio-economic status. ${ }^{108}$ Thus, it is not educational attainment as such, rather it is the ability to go to college that correlates with racial attitudes. The relationship between the police and higher education is unique. College graduates don't become policemen; potential policeinen go to police science departments of colleges to become policemen. ${ }^{107}$ Were they not interested in becoming

102. Interview with Prof. R. Jarrett, Psychology Department, University of California at Berkeley, in Berkeley, California, Dec. 12, 1968. Professor Jarrett suggests that the increase in the proportion of satisfactory policemen is not worth the cost of rejecting great numbers of qualified men. See Jarrett, Per Cent Increase in Output of Selected Personnel as an Index of Test Efficiency, 32 J. APPLIED Psychology 135 (1948).

103. A comprehensive program of psychological testing may, however, exclude all candidates.

104. CRIME COMM'N, supra note 29, at 109-11.

105. Not only are blacks disadvantaged in terms of grades completed in school, United States Bureau of the Census, Statistical Abstract of the Untted States 106 (90th ed. 1969), the quality of that education is far below that of a comparable white. See R. CoNot, supra note 40, at 436-37. See also J. Coons, Educational Opportunity: A Workable Test for State Financial Structures, 57 CALIF. L. REv. 305 (1969).

106. A. Niederhoffer, supra note 36 , at 152 , citing S. LIPSET, Political MaN 84 (1963).

107. See id. at $39,41,42,50,175$. Niederhoffer also suggests that it would be extremely difficult to recruit college graduates, as their college experience would direct them toward an occupation with higher status. See id. at 42. 
policemen, they would probably not go to college. There is no reason that this educational background will equip a policeman to understand problems stemming from different cultural and moral standards.

\section{Community Relations Units}

Many pohice departments have instituted commumity relations units-special units of the police department created to serve as a liason between the police and the community. ${ }^{108}$ Commissions established to study the police function liave recommended them as a satisfactory method for improving pohice-community relations. ${ }^{109}$ A realistic appraisal, however, suggests that these units have not significantly improved police-community relations.

The major problem with such units is that regular police officers have not worked well in conjunction with these units. Indeed, officers often work at cross purposes with these units and even attempt to destroy them. ${ }^{110}$ This is not surprising when one considers the conflicting roles involved.

Of necessity, community relations units and regular police units are under the direct control of two separate individuals, even if ultimate authority over both is vested in the chief of police. ${ }^{111}$ This presents a built in communications gap which is not easily overcome and which is widened when individual officers in each unit begin to stereotype their function in the crime control process. Regular pohice officers see themselves as protectors of the public order and, for various reasons, perceive a high level of public disorcler in the urban ghetto. This remforces the already negative view they have of ghetto residents. ${ }^{112}$ Such officers naturally see community relations units as illegitimate appeaseinents.

Community relations officers react in just the opposite way. If they have any understanding of the people they work with, and of their own job, ${ }^{113}$ they realize the extent of police harassment and brutality

108. See public relations materials from the New York City, Chicago, Memphis, Los Angeles, and New Orleans police departments describing suclı units (on file with the California Law Review).

109. CRIMe COMM'N, supra note 29, at 100-01; RIOT COMM'N, supra note 31, at $317-20$.

110. Both the Los Angeles and San Francisco police departments experienced this "in fighting." R. Conor, supra note 40, at 114. See also RIOT COMM'N, supra note 31 , at 320 .

111. See materials cited in note 108 supra.

112. See notes 38-42 supra and accompanying text.

113. Often they lack even this basic understanding. The San Diego, California Community Relations Unit of the Police Department considers itself a public relations unit and concentrates on image building. It seems to operate under the premise that its goal is to get the community to understand the police, not to help the police understand the community. CRIME COMm'N, The Police AND THE COMMUNITY, supra note 41, pt. II, at 164 . 
and some of the reasons behind high crime rates and hostility towards the police. They find present police practices unacceptable with regard to the job they are trying to do.

Yet, black residents are distrustful of community relations officers because they are police, no matter what role they are momentarily playing. ${ }^{114}$ In other words, the ability of community relations units to function satisfactorily is severely limited by the very problem they are trying to solve. If black glietto residents could trust and respect the police rather than fear and liate them, community relations units could function more effectively. But if mutual trust and respect were present, these units would no longer be uniquely police oriented and their functions could more adequately be performed by a different arm of local government. This "circular evolution" suggests that it is futile to expect blacks to clrange their attitudes toward the police when one unit tries to repair the damage inflicted by the other.

\section{E. Police Review Boards}

Reports have suggested ${ }^{115}$ and many cities have established ${ }^{116}$ agencies to review police beliavior. Theoretically, sucl an agencycommonly called a pohice review board or police commission-would have broad powers to imvestigate alleged abuses of authority by police and to take appropriate measures to punish offenders. ${ }^{117}$ In practice, these review boards lave not proven satisfactory. Two problems posed by review boards--establishing them initially and making them work after their establishinent-are demonstrated by the experiences of New York and Philadelphia.

The Philadelphia police review board demonstrates the ineffectiveness of such boards. Established in 1958, well prior to the development of the police as a political force, this board is often held out as a model for other cities to follow. However, even this model board is weak. It has no subpoena power or imdependent investigating power, so it must use the police-the very group being investigated-to get facts, and it must wait for civilian complaints before it can begin investigations. ${ }^{118}$ These civilian-initiated complaints are few in nunber, as it appears that residents fear repercussions from the police if they report their complaints. ${ }^{119}$

114. Crime Comm'n, TASK Force Report: The Police, supra note 86, at 151.

115. E.g., CRIMe COMM'N, supra note 29, at 103.

116. E.g., Crme COMm'N, The Police AND tHB CoMmuntTy, supra note 41, pt. III, at 205.

117. For a complete bibliography of works discussing police review boards, see Cray, Annotated Bibliography on Police Review Boards, 3 LAW IN Transition Q. 197 (1966).

118. See Crime Comm'N, The Police and the Communtry, supra note 41 , pt. III, at 213-87.

119. See id. at 164. 
The highest the Philadelphia board's budget has been since its establishment was 18,000 dollars, out of which 7,500 dollars went to pay the executive director. With this budget, the board has not been able to buy filing cabinets or other adequate record-keeping devices, let alone advertise to make people aware of its existence. At a salary of 7,500 dollars it las been difficult to hire a qualified director. The board can only recommend punishment and the final decision rests with the chief of police. Finally, the board has been out of operation for a year and a half during its eleven-year life: once when it was enjoined by the Police Association during a dispute over the board's naine, and once when the mayor failed to appoint a new director after the resignation of the first director. ${ }^{120}$

The New York experience demonstrates the difficulty of creating such boards. In 1965 the establishment of a police review board became a campaign issue in the mayoralty race. Despite the fact that the proposed board had little power-it had no imdependent investigatory power, a limited budget, could only recommend punishment, and did not have the power of subpoena-and that virtually all of the popular political figures-Lindsay, Rockefeller, Kennedy, Wagner-supported it, it was overwhelmingly defeated. The police department, through a well-financed and staffed campaign based on fear and bigotry convinced the people that even this board would seriously himder the functioning of the police. ${ }^{121}$ This campaign demonstrated that in matters of police policy, the public tends to defer to the judgment of the "professionals."

These weaknesses do not suggest that police review boards should be abandoned. Although it is generally recognized that the Philadelphia board lias done little to ease police-black tensions, ${ }^{122}$ those who have been exposed to the board have felt that they were treated fairly. Cities desiring to enhance police-community relations should attempt to establish effective review boards, but they should not consider the establishment of such a board the end of the probleins of police-coinmunity relations.

\section{F. Injunctions}

Theoretically, the proper solution to this problen of police brutality is the injunction. By getting a court order requiring police officials to stop their officers from using larassinent, brutality and discriminatory enforcement of the law, the black commumity would be

120. See id. at 213-87.

121. See the unpublished manuscript of D. Jaffe, The Police Review Board Controversy: A Study in Issue Formation, and sources cited therein (on file with tho California Law Review).

122. See generally, CRIME COMM'N, THE POLICE AND tHE COMMUnity, supra note 41 , pt. III, at 205-87. 
protected from such unlawful practices. If the police continued to engage in such practices, more specific orders dealing directly with police conduct could be issued. If these measures proved ineffective, the court would ultimately have to deny further relief or, if blame could be attached to specific officials, they would be subject to criminal sanctions, mcluding contempt. ${ }^{123}$

Injunctive relief is an inadequate response to discriminatory law enforcement because of the nature of the problem. It is not each arrest individually tested which unanifests the problein; rather it is the existence of practices which result in otherwise legitimate arrests of blacks when whites in similar circumstances would not be arrested. Thus, a court which ordered nondiscriminatory enforcement could not find a violation based on any particular arrest. Unless the courts are prepared to engage in a continuing researcli project-forcing the complaining attorney to canvass white and black neighborhoods to prove blacks are more frequently arrested than whites in any given situation-this remedy would be useless. The only alternative is proscribing arrests without warrants absent inuch more than probable cause-an alternative which obviously endangers effective crime control.

Injunctive relief is no more adequate in stopping extra-legal behavior. Police abuse is very often "invisible"--only the police officers and the abused party are present. A court issuing an injunction agamst abusive tactics would have to accept uncorroborated testimony. If the court is willing to review police behavior on this evidence and impose penalties, the court could easily go one step further and find the police structure constitutionally inadequate, thus obviating the need for imposing punishment while more effectively protecting the rights sought to be protected by the restraining order.

\section{G. Summary}

All of the solutions suggested by the commissions concerned with the problem of police brutahity are undoubtedly the products of a good faith desire to eradicate the inequities stemming from poverty and race. But it is the very fact that race is central to the problem that will make such proposals futile. Simply stated, the white (or black) policeman on today's urban police force represents too adequately, too vividly, and too well white society's historical and present policy of white suprennacy. That this pohicy is rarely publicly stated does not detract from the fact that it nevertheless exists and nnanifests itself every day in numerous ways to the people of the urban black ghetto. The only satisfactory method of assuring equal and satisfactory police protection in the ghetto is to establish a black police force, responsive to the problems and needs

123. Note, The Federal Injunction as a Remedy for Unconstitutional Police Conduct, 78 YALE L.J. 143 (1968). 
of the ghetto and ghetto residents. It is only after this has been done that economic and educational programs can have the impact and results contemplated by their framers.

\section{IV}

\section{NEIGHBORHOOD POLICE DISTRICTS AND THE FOURTEENTH AMENDMENT}

Thus far, this Comment has explored three areas: The traditional attitude of courts toward the use of race in determining legislative or administrative classifications, ${ }^{124}$ the denial of equal protection to the urban black by present police practices, ${ }^{125}$ and the imadequacy of the more "popular" solutions as remedies for this problem. ${ }^{120}$ This Part will define neighborliood police districts, show why they are a satisfactory solution to the problem, and demonstrate that these districts are not proscribed by the fourteenth amendment.

\section{A. What is a Neighborhood Police District?}

The essence of a plan of neighborhood police districts is the drawing of neighborliood boundary lines so as to include, as completely as possible, the black community in one district and the white community in the other. ${ }^{127}$ Depending on the size, nieasured both by land area and by population, the resulting districts could be subdivided as administratively convenient, taking into consideration the population, crime rate, area, and socio-economic status of the internal neighborhoods. The two districts could share certain facilities-a central crime laboratory, central files, a joint system of patrol car dispatching. Each district, however, would be administratively autonomous and free to establish its own procedures, including requirements for employment in the department..$^{128}$

Separate police commissions made up of representatives elected from each neighborlood would control the two district departments. These commissions would have the ultimate responsibility for all decisions concerning their respective departments. Certain responsibility could be delegated, if desired, to the chiefs of police of the departments. Each department would establish its own hiring, patrol, investigating, and specialized procedures, depending on the needs of the district as

124. See Part I supra.

125. See Part II supra.

126. See Part III supra.

127. See map attached to Proposed Amendment to the Charter of the City of Richmond, California, supra note 81 . This division established districts which are respectively 80 percent black and 99 percent white.

128. This Comment will not suggest that this precise method is constitutionally required. It is only the initial concept which both meets, and is faced with, constitutional problems. Details such as the composition of police commissions, the use of central facilities and the subdivisions of the main districts would all be within the discretion of each city. 
determined by the police commission. The commissioners would stand for election in their district and would be subject to recall as would any other elected official.

\section{B. Why Neighborhood Police Districts?}

Although the problem of the urban black is complex and not soluble by any one plan, it is apparent that the presence of white police officers, for a number of reasons, causes a great deal of friction between the residents and police. This friction is largely responsible for difficulties in black-white relations generally and specifically the distrust of government. Neighborhood police districts will effectively remove the irritant from the black ghetto.

Equally important, neighborlood police districts replace white policemen with officers who have moral and cultural backgrounds similar to those of the residents. This would facilitate police understanding of the problems faced by ghetto residents. Having been subjected to the same kind of abuse and discrimination as the black residents, the police would be loathe to use these tactics themselves. Living in the neighborhood, they would speak the same language as the residents, ${ }^{129}$ allowing the two groups to communicate more effectively.

The need for black police in black communities cannot be met by recruitment of black officers into police forces as presently structured. As previously noted, ${ }^{130}$ black police under the present systein inust disassociate themselves from the black community to be suitable for promotion and disassociation often takes the form of brutality toward blacks. The district system would eliminate this by removing the need for disassociation. ${ }^{131}$

The black community would probably have inore respect for a district department. Residents would see blacks in positions of authority and responsibility. They would undoubtedly see a noticeable decline in mcidents of harassment and brutality, and would realize that

129. During the trial in Oakland of Huey Newton, a leader of the Black Panther Party, for the murder of an Oakland policeman, testimony was presented establishing the fact that blacks really did use the language differently than whites and often meant things completely different than they seemed to be saying. See also THE AUTOBIOGRAPHY OF MALCOLM X, supra note 59, at 310.

130. See notes 92-94 supra and accompanying text.

131. This argument is also applied against neighborhood police districts. The criticism is that the desire and need for community and neighborhood approval will lead to an overly permissive police department. This, of course, assumes that ghetto residents would approve of permissive practices. This assumption is false. Although there is currently widespread disapproval of the police department, there is virtual unanimity in general support of the police function. CrIme COMM'N, The Police AND THE COMMUNITY, supra note 41 , pt. II, at 78. In fact, a major complaint about present practices is that the potice are too permissive when it comes to certain crimes committed in the ghetto-specifically those involving black victims. RIOT CoMM'N, supra note 31 , at 307-09. 
this police force is not in the ghetto to preserve white supremacy. Such increased respect would help immensely in obtaining cooperation, easing tensions and improving relations.

Finally, through the police commissions and officers who speak the same language, ghetto residents would be put back into communication with the most visible elements of government. They could be reinstated to a position of governmental decisionmaking. Through their collective voice they could change practices that are particularly offensive to blacks.

Neighborhood police districts would inprove the image and quality of the entire judicial system. Knowing that he was not arrested because of racial prejudice by police, a black defendant would come to see the law and the criminal process in nonracial terms. Youths would not have arrest records simply because they are black and on the streets. ${ }^{132}$ Respectable businessmen would not be stopped and interrogated on the streets simply because they are black. ${ }^{133}$ Women would not be questioned on suspicion of prostitution simply because they are black. ${ }^{134}$ Arresting officers would not be predisposed in their opinion of a suspect because of his race. Black officers would see incidents through the eyes of a resident of the area, and would be able to "translate" for the judge. ${ }^{135}$ In short, within the framework of existing laws, race would becoine irrelevant to the administration of justice. ${ }^{136}$

\section{Constitutionality of Neighborhood Police Districts ${ }^{137}$}

This Comment has already demonstrated that police harassment and brutality toward blacks is a deprivation of equal protection. ${ }^{188}$ This section will again consider the equal protection clause, but in another context: the establishment of neighborhood police districts on racial lines. At first glance, racial districting would seein clearly prohibited by the language and interpretation of the equal protection clause. ${ }^{130}$ An analysis more consistent with the spirit of the fourteenth

132. See R. Conor, supra note 40 , at 110 .

133. See id. at 311.

134. See id. at 147.

135. See note 129 supra.

136. It is not suggested that all law enforcement problems stemming from race will be solved through community control. General laws reflecting white middle class norms will continue to operate oppressively on blacks due to different social conditions and values. As long as blacks continue to be politically underepresented in the legislative process this oppression will exist.

137. This section will consider any impediments imposed by the United States Constitution. Any state constitutional or statutory impediment will have to be determined by local authority. In California there is no constitutional barrier to charter cities establishing their own system of police protection. CaL. Const. art. 11, § 81/2(3).

138. See Part II, section B supra.

139. See, e.g., Gomillion v. Lightfoot, 364 U.S. 339 (1960). 
amendment, however, suggests that not only is such a scheme constitutionally permissible, but may in some cases be required.

\section{Minimum Requirements of Fourteenth Amendment Equal Protection}

Since its adoption in 1868, the fourteenth amendment has been the subject of a wealth of controversial scholarly and judicial commentary. Many modern critics argue that the courts have expanded the scope of the amendment beyond its legitimate limits. ${ }^{140}$ Some commentators have argued that education ${ }^{141}$ and marriage, ${ }^{142}$ among other areas, were not intended to fall within the ambit of the amendment. But even the critics of recent expansion admit that at least one of the major purposes of the amendment was to protect the Negro froin the kinds of discrimination levied against him by the legal structure of the ante-bellum South. ${ }^{143}$ This purpose was not extinguished with the passing of Reconstruction. ${ }^{144}$ The equal protection clause has been used in the 20th century to strike down discrimination in housing, ${ }_{9}^{145}$ education, ${ }^{146}$ and public accommodations, ${ }^{147}$ none of which is inore fundainental to the preservation of the freedom of an individual or a race than is the right to be free from harassment, intimidation, and brutality from the one arm of government charged with the duty of protecting the individual from those very crimes it is guilty of perpetrating. To suggest that neighborhood police districts would violate the equal protection clause because they employ a classification based on race would be using the Constitution as a sword against the very people it seeks to shield. That such a doctrinal result would be intolerable is the premise from which the subsequent examination of relevant equal protection doctrine proceeds.

\section{2. “Constitutionally Suspect” Doctrine}

The doctrine that racial classifications are "constitutionally suspect" was first enunciated in Hirabayashi v. United States ${ }^{148}$ and Kore-

140. E.g., Avins, supra note 60.

141. Brown v. Board of Education, 347 U.S. 483 (1954).

142. Loving v. Virginia, 388 U.S. 1 (1967); McLaughlin v. Florida, 379 U.S. 184 (1964).

143. See Frank \& Munro, The Original Understanding of "Equal Protection of the Laws", 50 ColUM. L. Rev. 131 (1950).

144. Cf. Monroe v. Pape, 365 U.S. 167 (1961).

145. Mulkey v. Reitman, 64 Cal. 2d 529, 413 P.2d 825, 50 Cal. Rptr. 881 (1966), affd Reitman v. Mulkey, 387 U.S. 369 (1967); Chicago Real Estate Bd. v. City of Chicago, 36 III. 2d 530, 551, 224 N.E.2d 793, 807 (1967).

146. Brown v. Board of Education, 347 U.S. 483 (1954).

147. Lonbard v. Louisiana, 373 U.S. 267 (1963).

148. 320 U.S. 81 (1943). 
matsu $v$. United States, ${ }^{140}$ both cases dealing with the special treatment of Japanese-Americans during World War II. Although the Supreme Court sustained both the curfew upon and relocation of Japanese-Americans, it issued a strong warning that such classifications would generally not be tolerated. ${ }^{150}$ The judiciary has invoked this doctrine many times since then to void racial classifications. ${ }^{151}$ A closer look at the language and intent of the Court reveals that this warning was directed only at racial classifications which curtail civil rights.

In Korematsu, the Court prefaced its opinion by saying:

It should be noted, to begin with, that all legal restrictions which curtail the civil rights of a single racial group are immediately suspect. This is not to say that all such restrictions are unconstitutional. It is to say that courts must subject them to the most rigid scrutiny. Pressing public necessity may sometimes justify the existence of such restrictions; racial antagonism never can. ${ }^{162}$

The "pressing public necessity" disclaimer was the basis for upholding the relocation of Japanese-Americans as a needed precaution against possible espionage.

The significance of the cases which followed Hirabayashi and Korematsu is that they all struck down statutes, ordinances and executive orders that "curtailed the civil rights of a single racial group." In Gomillion v. Lightfoot ${ }^{153}$ there was such a curtailment, as blacks were systematically excluded from voting in mumicipal elections. When school enrollment is deterinined in this manner there is such a curtailment, as blacks are precluded froin attencling satisfactory schools and are denied freedom of association. ${ }^{154}$ These classifications are the archetype of constitutionally suspect classifications since they act to deprive a racial group of its rights. The public necessity exemption nay be used to sustain such classifications as in Korematsu, but they nevertheless nuust be considered initially suspect and "subject to the most rigid scrutiny."

To invoke the "constitutionally suspect" doctrine requires more than the use of race; it requires the use of race in a system of classification that deprives a classified race of its civil rights-thereby depriving its members of full societal participation-either on the face of the statute or in its application. This requires an examination not only of

149. 323 U.S. 214 (1944).

150. Hirabayashi v. United States, 320 U.S. 81, 100 (1943).

151. E.g., Loving v. Virginia, 388 U.S. 1, 12 (1967) (anti-miscegination laws); Oyama v. California, 332 U.S. 633, 646 (1948) (restriction on alien land ownership); Bynum v. Schiro, 219 F. Supp. 204, 208 (1963) (segregation in city auditoriuin).

152. 323 U.S. 214, 216 (1944) (emphasis added).

153. 364 U.S. 339 (1960).

154. See Brown v. Board of Education, 247 U.S. 483 (1954). 
the system of classification, but also of the results of the statute's application $^{155}$ and effect. ${ }^{156}$ The doctrine in Hirabayashi and Korematsu only provides an answer in the extreme cases in which civil rights are curtailed on the face of a statute. Neighborhood police districts do not deprive a racial group of these civil rights and thus further analysis is necessary in order to determine their validity.

\section{Reasonable Relationship to Legitimate State Function}

The Constitution does not require things different in fact to be treated in law as if they were the same. ${ }^{157}$ A classification is permissible if it is reasonably related to a legitimate state function. If all classification were unconstitutional, welfare programs would have to be abandoned as they classify on the basis of wealth; ${ }^{168}$ civil service advantages for veterans would have to be abandoned as they classify on the basis of military service, ${ }^{169}$ and Medicare would have to be discontinued as it classifies on the basis of age. ${ }^{100}$ All citizens would have to be able to vote, regardless of their age, ${ }^{161}$ and all drivers would liave to be licensed, regardless of their competence. ${ }^{162}$ No one seriously contends that such classifications are unconstitutional. In all these examples, the groups separated by the classifications are sufficiently different and the difference sufficiently related to legitimate state functions to justify the classifications. In sliort, reasonable classifications such as these do not manifest the invidious discrimination proscribed by the fourteenth amendment. ${ }^{163}$

Under this test the Supreme Court has had the opportunity to examine many aspects of racial classifications. In so doing, the Court has developed several variants of the basic test, all voiding statutes that deprive a class of equal societal rights. In Buchanan v. Warley ${ }^{164}$ the Supreme Court struck down an ordinance restricting the sale of property to Negroes. The Court said that by restricting the sale of property, despite the seemingly legitimate purpose of preventing racial hostilitywhich could be asserted for every racial classification-the ordinance

155. See Yick Wo v. Hopkins, 118 U.S. 356 (1886) (statute neutral on its face applied discriminatorily by officials).

156. See Gomillion v. Lightfoot, 364 U.S. 339 (1960) (voting districts apparently neutral until viewed in operation).

157. Tigner v. Texas, 310 U.S. 141, 147 (1940).

158. E.g., CAL. Welf. \& INST'NS CODE $\$ \$ 18500-04$ (West 1966).

159. E.g., 5 U.S.C. $\$ 645 \mathrm{c}$ et seq. (1964).

160. 42 U.S.C. $\$ 1395$ (Supp. IV, 1965-68).

161. E.g., CAI. CoNST. art. II, $\$ 1$.

162. E.g., CaL. Vehicle Code $\S \S 12803-04,12814,13801$ (West Supp. 1969).

163. Williamson v. Lee Optical Co., 348 U.S. 483 (1955) (statute regulating opticians but not ready-to-wear glasses seller is constitutional).

164. 245 U.S. 60 (1917). 
directly contravenes the fourteenth amendment prohibitions. ${ }^{105}$ It went on to say that the problem of racial hostility cannot be solved by depriving citizens of their constitutional rights. ${ }^{108}$ In other words, the Court would not allow the city to assert this as a legitimate state function, even if the problem did exist.

The Court used this analysis to strike down segregation in public parks. Wright v. Georgia ${ }^{107}$ overturned the conviction of Negro youths who were playing basketball in a public park. The convictions purportedly were for disturbing the peace, but were in fact a manifestation of official hostility toward integrating public facilities. ${ }^{108}$ The Court said that there was no evidence of any public disorder, ${ }^{100}$ and that even had there been disorder on the part of others it would not justify the deprivation of the youths' constitutional rights. ${ }^{170}$ Watson v. City of Memphis $^{171}$ went even further. Here there was no "side issue" of a conviction for disturbing the peace. The Court was reviewing a gradual desegregation plan for city parks. The city gave two reasons for the slow pace of desegregation: the hostility of the people of Memphis and the additional cost of maintenance and staffing due to increased use if the parks were totally integrated. The Court refused to accept these assertions, saying that they were not consistent with the facts. ${ }^{172}$ It went on to say that constitutional rights cannot be denied simply because of hostility to their exercise ${ }^{173}$ or because of the increased cost involved in affording them. ${ }^{174}$ In short, the city had shown no compelling or even reasonable basis for denying Negroes their constitutional rights. ${ }^{175}$

In Cooper v. Aaron, ${ }^{178}$ a case decided shortly after Brown $v$. Board of Education, ${ }^{177}$ the Supreme Court held that a plan of desegregation could not be halted because of threatened violence. The Court said that "law and order are not here to be preserved by depriving the Negro children of their constitutional rights."178 Thus, under the basic

165. Id. at 73.

166. Id. at 81 .

167. 373 U.S. 284 (1963).

168. Id. at 292.

169. Id.

170. Id. at 292-93.

171. 373 U.S. 526 (1963).

172. See id. at 535-37.

173. Id. at 535 .

174. Id. at 537 .

175. Id. at 539. Cf. Anderson v. Martin, 375 U.S. 399 (1964) (requirement of putting race of candidates on ballot unconstitutional).

176. 358 U.S. 1 (1958).

177. 347 U.S. 483 (1954).

178. 358 U.S. at 16. The similarity in language between Buchanan and Cooper indicates that, above all else, the constitutional rights of the individual must be protected. Buchanan classified the right to dispose of one's property and to live where 
test of reasonableness, the Court said that not only would it not accept potential violence as a legitimate reason for curtailing civil rights, it would not accept actual violence in Cooper as a legitimate reason.

In two recent cases, the Supreme Court dealt with racial classifications which vividly exemplified the historic purpose of such classifications and thus enabled the Court to develop the most reahstic test of their vahdity. McLaughlin v. Florida ${ }^{179}$ and Loving $v$. Virginia ${ }^{180}$ declared unconstitutional state statutes punishing, respectively, cohabitation by interracial couples and interracial marriages. These statutes were designed to maintain the separation of the races at a most basic level-sexual activity. They clearly represented an attempt to maintain white supremacy ${ }^{181}$ in that they were aimed at the one image most loathed by Southern whites. ${ }^{182}$ They thus represented all that can be objected to in a racial classification: an attempt to keep blacks "in their place" and maintain two societies-one black and one whitewith the white society dominant. In this respect they were merely part of an entire scheme of legislation, ranging from segregation in hous$\mathrm{mg}^{183}$ to segregation in education, ${ }^{184}$ designed to separate the races. It is such classifications which the equal protection clause prohibits.

In McLaughlin the Court began by overturning an earlier interpretation of the fourteenth annendment that it now found to be of hinited value. The Court rejected the assertion in Pace v. Alabama ${ }^{185}$ that equality of application was all that was necessary to sustain a law based on racial classifications. ${ }^{186}$ Implicit in Pace is an acceptance of the legislative determination that similar acts are in fact different when done by members of different races, thus requiring different laws. ${ }^{187}$

one wanted as a right protected under the fourteenth amendment. Cooper classified the right to an cqual education as a right protected by the fourteenth amendment. Compare these rights with the right to protection from police discrimination.

179. 379 U.S. 184 (1964).

180. 388 U.S. 1 (1967).

181. Id. at 11 .

182. This resentment is not limited to Southern whites. There is a strong possibility that the three black youths killed by police during the Detroit riot of 1967 in the Algiers Motel were killed at least partly because they were there with white girls. J. HERSEY, supra note 54, passim.

183. E.g., Buchanan v. Warley, 245 U.S. 60 (1917).

184. E.g., Brown v. Board of Education, 347 U.S. 483 (1954).

185. 106 U.S. 583 (1883).

186. 379 U.S. at 188 .

187. The statute in Pace proscribed illicit sexual activity between white and black partners and provided a greater penalty than a similar statute proscribing the same offense without regard for color. In sustaining the statute, the Court recognized that the purpose of the fourteenth anendment was to prevent discriminatory legislation against any class of people, and to provide equality of punishment for the same offense; but argued that the legislature characterized these activities as two different ones, and that there was no discrimination as all violators of each statute were 
By rejecting Pace, the Court opened the way for the examination of both the coinpelling need for the legislation to achieve its stated purpose and the legitimacy of the effective result-with the inajor emphasis on the latter. This analysis is an obvious departure from past tests which seemed to indicate the possible legitimacy of legislation which deprived classes of certain rights, on the theory that situations could compel such classifications.

With this formulation of the equal protection test, the Court could find the statutes unconstitutional in two ways. If it decided that the purpose of the statute in McLaughlin was to prevent indecent sexual activity, the classification would be invalid as not compelled to achieve that purpose, as there already was a statute prohibiting illicit sexual activity generally. If it decided that the purpose was to separate the races through the enactinent and enforceinent of legislation that, in effect, punished people for being of different races and participating in certam behavior, the Court could strike down the statute as an illegitimate exercise of state power.

If McLaughlin is unclear as to which test was used, Loving is certainly clear. The Court makes repeated reference to the purpose of the antimiscegenation statute being one of inaintaining white supreinacy ${ }^{188}$ and preserving racial integrity. ${ }^{189}$ The statute undoubtedly is compelled if this is to be achieved, but the Court found that this end violated the central purpose of the fourteenth amendment in that it restricted an individual's freedom because of his race and could have no other purpose than to inaintain white supremacy. ${ }^{100}$

The developinent of the "reasonable relation" test, as seen in these cases, demonstrates the changing attitude of the Court toward racial classifications. Early in the development of the test, the Court refused to allow potential violence to justify such classifications. Later, actual violence requiring federal troops was deemed insufficient. In effect, the Court held that no situation could be compelling enough to sustaim classifications which deprived a group of constitutionally protected rights. With this background, it would seem that the Court could have easily disposed of the classifications in McLaughlin and Loving, as the reasons for the classifications advanced by the states were not nearly as compelling as the violence advanced in earlier cases. However, the Court discussed these classifications at length and found thein unconstitutional only after strong suggestions that it considered them in existence

treated equally. 106 U.S. at 584-85. Acceptance of this doctrine allows states to establish two parallel sets of laws-one for blacks and one for whites-on the theory that race is a legitimate basis for the characterization of an activity.

188. 388 U.S. at 7, 11.

189. Id. at 7.

190. Id. at 11 . 
purely to maintain white supremacy. The recognition that state legislatures passed virtually all racial classifications voided by the Court to date for the purpose of maintaining white supremacy and that these classifications deprived a group of rights held to be secured by the Constitution provides a sound basis for a reevaluation of the equal protection clause when it is applied to a racial classification that enhances racial justice.

\section{Substantive Equal Protection}

The cases considered to this point demonstrate the unusual position taken by the Court. While it has contimued to articulate the legitimacy of racial classification for compelling reasons, the Court has failed to find such compulsion even in extreme cases requiring the use of federal troops to ensure public safety. ${ }^{191}$ This conflict between words and acts has prompted many commentators to suggest that racial classifications can never be inade. ${ }^{192}$ A more realistic analysis of the equal protection clause, in light of some recent Court decisions, suggests that the "compelling state imterest" analysis can be successfully invoked when the racial classification under consideration does not deprive the classified groups of substantive equal protection.

In Morey v. Doud ${ }^{193}$ the Supreme Court, in unique equal protection language, invalidated an Illinois statute which severely restricted the sale of money orders by all companies except the American Express Company. ${ }^{194}$ This opinion is significant in that it overturned an economic regulation which clearly had a rational basis-consumer protection-in an era in which the Court paid complete deference to state legislative judgment in such matters. ${ }^{195}$ In so holding, the Court developed a "closed class" theory of the fourteenth amendment. That is, although a classification may meet all the traditional tests of reasonableness and necessity, it will not be sustained if it also prohibits access into a closed class. The fact that the Court refused to defer to the legislature's judgment in the field of economic regulation, a field marked by judicial deference, indicates that class closing is at the heart of the equal protection clause, and that equal protection might afford a substantive

191. Cooper v. Aaron, 358 U.S. 1 (1958).

192. See Hellerstein, The Benign Quota, Equal Protection, and "The Rule in Shelley's Case," 17 RuTGers L. REv. 531, 549-50 (1963); Kaplan, Segregation Litigation and the Schools-Part I: The New Rochelle Experience, 58 Nw. U.L. REv. 1, 22 (1963).

193. 354 U.S. 457 (1957).

194. \& 1, 1 [1943] IIl. Laws 233.

195. See, e.g., NLRB v. Jones \& Laughlin Steel Corp., 301 U.S. 1 (1937) (constitutionality of National Labor Relations Act upheld under authority of commerce clause); Umited States v. Darby, 312 U.S. 100 (1941) (constitutionahity of Fair Labor Standards Act upheld under authority of commerce clause). 
right to be free from denial of access to the class of those receiving the benefits of full societal participation.

If racial classifications are judged by this neutral standard, a classification which closes a class-that is, impedes access of blacks to the benefits shared by whites-violates equal protection; one which opens a class-that is, facilitates access of blacks to the benefits enjoyed by whites-does not. Although the Supreine Court has yet to speak on de facto school segregation, and lower court opinion is at best divided, plans using racial classifications to end such segregation have been sustained under what appears to be this approach. In Tometz v. Board of Education, ${ }^{196}$ the Illinois supreme court sustained the Armstrong Act ${ }^{107}$ -which required school boards to act affirmatively to remedy racial imbalance-and upheld a plan under that Act which took race into consideration. Citing heavily from cases in other states upholding similar plans, the court constructed an opinion couched in "class opening" language:

It would seem no more unconstitutional to take into account plaintiffs' special characteristics and circumstances that have been found to be occasioned by their color than it would be to give special attention to physiological, psychological or sociological varianees from the norm occasioned by other factors. That these differences happen to be associated with a particular race is no reason for ignoring them. ${ }^{108}$

The court went on to quote froin Morean v. Board of Education, ${ }^{100}$ which upheld a similar plan. In what seems to be the essence of the class opening theory, the New Jersey court said:

Constitutional colorblindness may be wholly apt when the frame of reference is an attack on official efforts toward segregation; it is not generally apt when the attack is on official efforts toward the avoidance of segregation. ${ }^{200}$

The Tometz court concluded that the classifications before it were also consistent with the fourteenth amendinent's requirement of reasonableness. ${ }^{201}$

There is another precedent for using racial criteria to aid in the realization of fundamental rights. In Georgia v. Rachel, ${ }^{202}$ the United

196. 39 IIl. 2 d 593, 237 N.E.2d 498 (1968).

197. Ilt. ANN. Stat. ch. 122 (West 1962). "As soon as practicable and from time to time thereafter, the board shall change or revise existing attendance units or create new units in a manner which will take into consideration the prevention of segregation and the elimination of separation of children in public schools because of color, race or nationality." Id. at $\int 10-21.3$.

198. 39 Ill. 2d at 598-99, 237 N.E.2d at 502, citing Booker v. Board of Education, 45 N.J. 161, 212 A.2d 1 (1965).

199. 42 N.J. 237, 200 A.2d 97 (1964).

200. Id. at $243-44,200$ A.2d at 100.

201. 39 Ill. $2 d$ at 602,237 N.E.2d at 503.

202. 384 U.S. 780 (1966). 
States Supreme Court found occasion to construe the Civil Rights Removal Act. ${ }^{203}$ That Act permits civil or criminal defendants faced with a state court action to remove their case to federal court if they cannot otherwise enforce rights under federal law protecting "equal civil rights." The case arose from a prosecution of 20 persons under criminal trespass laws during a 1963 restaurant sit-in. The petitioning defendants, in requesting removal, alleged that they would be denied rights protected by the first and fourteenth amendments and the Civil Rights Act of $1964^{204}$ if the trial was held in the state court. In a wellreasoned opinion, the court traced the history of the Civil Rights Removal Act and concluded that the statute's reference to "equal civil rights" referred exclusively to laws "providing for specific civil rights stated in terms of racial equality." the petitioners could only obtain removal based on a violation of the Civil Rights Act of $1964^{208}$ but not on the alleged first and fourteenth amendment violations, as rights so protected are not couched in racial terms. ${ }^{207}$ Since there had been no hearing as to the question of racial discrimination, the Court remanded the case to the district court with instructions that, should such allegations be proved, the defendants would be entitled to removal. ${ }^{208}$

The importance of Rachel for this Comment is the recognition by the Supreme Court of a legitimate use of a racial classification to enforce rights protected by federal law. It is clear that if this same racial classification-blacks or blacks and whites acting together-were used to impose a disability or to further state interests of white supremacy, the Court would find a violation of the equal protection clause. If used by the federal government, it would deny the substantive equal protection of the fifth amendment's due process clause. ${ }^{209}$ In sustaining the possibility of removal, the Court intplicitly recognized the lack of neutrality of the status quo and approved this procedural classification as a method

203. 28 U.S.C. $\$ 1443$ (1964). This section has two provisions, the first of which was explored in Rachel. The second, providing for removal to a federal district court of a prosecution brought for any act done under color of laws providing for equal rights, was explored in the companion case of City of Greenwood v. Peacock, 384 U.S. 808 (1966). For a discussion of these cases and other methods of entering federal courts, see Comment, Federal Removal and Injunction to Protect Political Expression and Racial Equality: A Proposed Change, 57 CALIF. L. Rev. 694 (1969).

204. 78 Stat. 241,42 U.S.C. $\S 2000 a-1$ (1964).

205. 384 U.S. at 792 .

206. 78 Stat. 241,42 U.S.C. $\$ 2000 a-1$ (1964).

207. 384 U.S. at 792. The Civil Rights Act was interpreted in Hamm v. City of Rock Hill, 379 U.S. 306 (1965), which held that the Act precluded state trespass prosecutions for peaceful attenpts to be served equally in covered establishments.

208. 384 U.S. at 805.

209. See Loving v. Virginia, 388 U.S. 1 (1967); McLaughlin v. Florida, 379 U.S. 184 (1964). 
of opening the class of persons who, in the future, were to be subject to equal protection of the laws. This analysis can be used to justify the constitutionality of neighborhood police districts. The state interest here is to protect its citizens from violations of the law and to prevent such violations from occurring in the first place, to protect its citizens, in this instance its black citizens, from brutality and harassment inflicted upon them by police officers and to open the channels of communication between blacks and the legal system. That neighborhood police districts are reasonably related to this end has been shown previously. 210 In the effort to achieve this goal, personal liberties and freedom of activity are not restricted. ${ }^{211}$ If anything, they are enhanced by the opening of potential employment, equal enforcement of the laws, and the end of fear toward an official arm of the state. Rather than contributing to a class closing system of white supremacy, neighborhood pohice districts will open the class of those equally protected by removing the one element that, perhaps unintentionally, most actively supports white supremacy.

The class opening theory of the equal protection clause is not $\mathrm{m}$ consistent with the more traditional interpretations of the fourteenth amendment. In the line of cases extending from Brown to Loving, the Court recognized the historical purpose of racial classifications. AIthough the Court has used language indicating its disapproval of racial classifications as applied, it has never struck down a class opening classification. The Court's reticence to speak in language conclusively invalidating all classifications, and its recognition of a distinction between class opening and class closing state action seems strongly to suggest the constitutional permissibility of neighborhood police districts subject only to the general requirement of reasonableness. The recognition of racial inequities in police behavior is no more difficult than the recognition of those same inequities in urban school districting and law enforcement in many Southern states. Finally, if the Court is in fact examining the motives behind classificatory legislation, a class opening analysis more accurately reflects the judicial process employed than do any of the traditional analyses and gives considerably more substance to the equal protection clause.

210. See Part IV, sections A and B supra.

211. It can be argued that by requiring police officers to be residents of the district they patrol restricts an individual's right to work where he pleases. However, many police departments and, for that matter, entire city governments, have residence requirements for employment. Such restrictions are based on the ground that city residents will do a better job since they have a personal interest in the community. Since black areas' are, in effect, separate cities with distinct problems, district residence requirements have as inuch validity as city residence requirements. Cf. 32 C.F.R. $\$ 1604.52 \mathrm{c}(1969)$ (members of local draft boards shall be, if practicable, residents of the geographical area over which the board has jurisdiction). 


\section{Use of Race Required}

Racial classification is "constitutionally suspect" because the overwhelming number of such classifications continue a pohicy of white supremacy and cannot pass the "reasonable relation to legitimate state function" test. There can be no objection to the continuation of the constitutionally suspect doctrine, in light of the history of race relations, as long as the analysis ultimately turns on whether the classification in question closes a class by effectively maintaining white supremacy or opens a class by attempting to eradicate racial disabilities. ${ }^{212}$ Once it is accepted that racial classifications may be as legitimate as any other classification, it can be demonstrated that, in some instances, they are required.

Two related developinents demonstrate the affirmative use of race to open classes previously closed by racial discrimination. In United States v. Sheet Metal Workers International Association ${ }^{213}$ the Court of Appeals for the Eighth Circuit substantially upheld an opinion of the Attorney General ${ }^{214}$ holding that umons must make their hiring and ranking procedures responsive to the inequities of past racial discrimination to remain eligible for federal contracts. The Union's work-referral system ranked workers for referral on the basis of past experience and, smce blacks had been seriously disadvantaged in obtaining work experience by past discriminatory Union activity, this system had to be changed to avoid perpetuating past discriminations. ${ }^{215}$. The court further held that the Union had an obligation to institute a periodic and intensive publicity program to offset the general behef that the Union discriminated against blacks. In essence, the court recognized the lack of neutrality in the status quo and required the affirmative consideration of race in remedying past discrimination.

In Green v. County School Board of New Kent County ${ }^{218}$ the Supreme Court reviewed a school board's "freedom-of-choice" plan $^{217}$ as

212. See Part IV, section C subpart 3 of this Comment.

213. 38 U.S.L.W. 2198 (8th Cir. Sept. 19, 1969).

214. Id. at 2191 (Justice Dept; OP. ATT'Y GeN., Sept. 22, 1969).

215. This is essentially the position taken by the Supreme Court in Lane v. Wilson, 307 U.S. 268 (1939), which held that a neutral voter's registration statute based on prior unconstitutional racial discrimination lead to continued unconstitutional discrimination and was therefore constitutionally inadequate. The clear implication is that the state must make an affirmative effort to correct past inequities.

216. 391 U.S. 430 (1968).

217. A "freedom-of-clroice" plan is essentially a plan for school assignment that requires the parents of school children to choose which school their children will attend. This selection occurs only in certain years, e.g., first grade, fifth grade, tenth grade, etc. Any child who has not filed a selection would be automatically assigned to the school he has previously attended. This method provided the least imtegration over the greatest period of time. UNTTED States COMM'N on CTVIE Rights, SouthERN SCKOOL DESEGREGATION, 1966-1967, at 88 (1967). 
a satisfactory program for implementing the decision in Brown v. Board of Education. ${ }^{218}$ The official board policy until Brown liad been one of de jure segregation of schools. After Brown, through various metlods, ${ }^{219}$ the scliool syste1n maintained segregation. In order to remain eligible for federal funds, the board adopted the "freedom-of-choice" plan for desegregation. The Court of Appeals for the Fourth Circuit affirmed the district courts' approval of the plan $^{220}$ and the case was brought to the Supreme Court.

In vacating the decision of the court of appeals and remanding to the district court, the Supreme Court recognized the racial history of the scliool board, its attempts to delay integration, and the fact that under the plan a minimal number of Negroes attended previously all white sclools. ${ }^{221}$ The Court lield that the scliool board could not shift the burden of affording equal educational opportumities from themselves to parents by requiring them to request specific assignments for their children. ${ }^{222}$ Finally, the Court said that in deciding whether a plan for desegregation satisfied Brown's edict, district courts had to look at the plan's effectiveness in eliminating segregation in practice, and that the burden is on the school board to effectuate a plan that works at once. $^{223}$ Freedoin-of-choice plans are only means to an end; and if that end is not reached while there are other more promising alternatives, then freedom-of-choice is not an acceptable solution. ${ }^{224}$

The facts of Green are analogous to the problem of discrimination by the police. Police practices are as effective in denying fundamental rights to blacks as de jure discrimination by race, and could be declared so by a Brown-type decree. Methods adopted by police departments to resolve the problem are not satisfactory. Only the establishment of neighborhood police districts can begin to meet the problem. The conclusion follows that:

It is incumbent upon the [city] to establish that its proposed plan promises meaningful and immediate progress toward disestablishing state-imposed [discrimination]. It is incumbent upon the district court to weigh that claim in light of the facts at hand and in light of any alternatives which may be shown as feasible and more promising in their effectiveness. Of course, the availability to the [city] of inore promising courses of action may indicate a lack of good faith; and at

218. 349 U.S. 294 (1955). This decision, referred to as Brown II, required desegregation of schools "with all deliberate speed."

219. 391 U.S. at $432-33$.

220. 382 F.2d 338 4th Cir. 1966). The district court maintained jurisdiction over the implementation of plans for school desegregation as required by the decree in Brown II.

221. 391 U.S. at $432-33$.

222. Id. at 441-42.

223. Id. at 439.

224. Id. at 440 . 
the least it places a heavy burden upon the [city] to explain its preference for an apparently less effective method. Moreover, whatever plan is adopted will require evaluation in practice, and the court should retain jurisdiction until it is clear that state-imposed [discrimination] has been completely removed.225

Once the stigma of racial classification is removed and it is seen as an acceptable classificatory criterion under certain circumstances, Green's requirement of a prompt and complete end to racial discrimination by the most effective means available necessarily requires the adoption of neighborhood police districts.

\section{Other Objections}

The most significant objection to neighborhood police districts is that they require classification based on race. Once this objection has been disposed of, the major problem is resolved. There are, however, two remaining arguments to be considered: the basic moral objection to ever using race as a standard, and the incompetence of courts to make legislative-type decisions.

\section{Basic Objection to Using Race}

Even if race is accepted as a constitutionally permissible basis for classification, there are those who object to its use for other reasons. They feel that any distinction based on race is a psychologically demeaning process and, as the distinction is ultimately unrelated to any distinction between human beings as human beings, will actually have effects worse than those attempted to be remedied. ${ }^{226}$

As an abstract proposition this argument cannot be challenged. However, the visible difference between black and white and 300 years of suppression have vividly demonstrated to every black American that white society regards him as different. The atrocities of slavery and the equally brutal-to the psyche-treatment of blacks since the Civil War have done more damage than can be adequately expressed. ${ }^{227}$ To suggest that the one classification that would in some way alleviate the pain and suffering imposed on the black people for so many years, protect him from physical abuse by an arm of the power structure that continues to oppress him, and aid immeasurably in restoring his pride as a human being is a psychological burden on him is to view the past 300 years as unrelated to the current feelings of black Americans. This is a restricted view that cannot be supported.

225. Id. at 439.

226. See Kaplan, Equal Justice in an Unequal World: Equality for the NegroThe Problem of Special Treatment, 61 Nw. U.L. REv. 363 (1966).

227. See W. GRIER \& P. CoBBS, supra note 46. 


\section{Incompetence of Courts}

The argument is made that courts are not competent to make what is essentially a legislative decision. This Comment recognizes that, given the nature of the evidence currently available, a court would have difficulty reconciling its role in establishing neighborliood police districts with its traditional role of settling discrete disputes between parties. There are, however, certain circumstances under which a court could legitimately act to further the establishment of neighborhood police districts consistent with its traditional functions.

Assuming that the legislative body responsible for city police organization (either a city council or state legislature) enacted a plan of neighborhood police districts, courts would be acting within their competence in upholding such a plan in the face of a constitutional attack by parties unhappy with the legislative choice. This, in effect, would entail both a deference to legislative judgment and a recognition that the use of racial classifications is permitted under certain circumstances. If the legislature finds that abusive police practices do exist on a large scale, but enacts something short of neighborhood police districts, a court would be acting within its competence to find the plan enacted an unsatisfactory solution to the problem. This is the approach taken in Green.

A sound argument can be made for judicial decision without legislative action. The pohice abuses about which ghetto dwellers complain are inherently difficult to establish by judicially cogmzable proof. Even if one claimant convinced a court that a series of specific acts did in fact occur, he would not thereby estabhish that those events were part of an all-pervasive behavior pattern. Many acts standing alone would not entitle a black to a personal remedy even if proved beyond a reasonable doubt. ${ }^{228}$ Police discretion and the low visibility of police actions, along with the subtle nature of much offensive behavior makes judicial recogmition difficult. It is that very reason-the lack of a satisfactory private remedy-that makes a constitutional remedy almost mandatory. Furthermore, the competing theories and positions can almost always be supported by sociological data. In Brown v. Board of Education ${ }^{220}$ the Court was faced with deciding between two schools of educational philosophy, both of which had merit. The fact that it chose one over the other indicated not its acceptance of a particular philosophy in a particular case, but rather a realization that, on a global scale, individual rights were more satisfactorily protected through integrated schools. The same recogmition, that individual rights are more satisfactorily protected through local control of police functions, regardless of specific

228. E.g., name-calling. See note 45 supra.

229. 347 U.S. 483 (1954). 
instances of proof in specific cases, would be entirely compatible with recent court decisions.

Finally, if courts refuse to act in this area, political realities dictate that neigliborhood police districts may never be established. Current societal attitudes make such legislation virtually impossible. If courts refuse to act by claiming incompetence, individual rights will continue to be sacrificed to the gods of political pressure and legislative abdication. This is, perhaps, the most compelling reason for courts to act.

\section{CONCLUSION}

Police brutality in the black urban ghetto may perhaps be resolved through neighborhood police districts. But it is important to understand that police brutality is only a manifestation of a greater problem. Institutional America is geared to a standard patterned after the middle class white American. That standard is currently too rigid to accommodate adequately the diversity that exists in contemporary society. With most other groups, the conflict is not as serious as it is with blacks because no other group in America has had the unique historical experience of slavery. No other group has been so consistently and so systematically discriminated against because of the color of its skin.

Despite the constitutional arguments presented in this Comment, community control of police departments is probably a long way from realization. Until then, the black community is goimg to be the recipient of countless stop-gap plans of police reform imposed by white middle class legislatures that think they know what is best for a people they cannot begin to understand. Institutional America will continue to respond in well intentioned ways to what it considers a "black problem" until it realizes that it is, im fact, a "white problem." Until then, the black can only listen to white society say: "I sit on a man's back, choking him and making him carry me, and yet assure myself and others that I am very sorry for him and wish to lighten his load by all possible means-except getting off his back."230

Jeffrey R. Freund

230. Attributed to Leo Tolstoy, written shortly before the Russian Revolution. 